\title{
皮膚内総 ビタ
}

第 4 編 ビタミン $\mathrm{B}_{1}$ 注射による血液內拾よび

皮䖉內総ビタミン $\mathrm{C}$ 量の消長

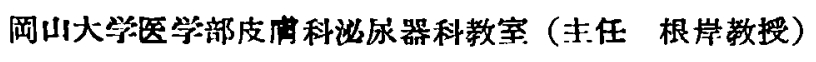

副手山崎輝男

[昭和 29 年 1 月 14 日受嚆]

\section{第1草腥言}

ピタミンR1は周知のごとく，1910年鉿木梅 太郎氏，1911 年英国の Funk が米粶から粗 製ピタミン $\mathrm{B}_{1}$ （以下V. $\mathrm{B}_{1}$ と記す）を抽出し て以来このるの関する研究は今日至るま で盛んに行われなお不明な点る多々存在す るが，現在ではとの作用機序も追々明らか、

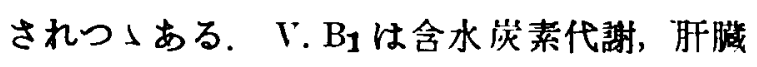
機能および副留皮質ホルモン，インンユリン 等の作用と密接な関係を有し,さらにこれら のすのを仲介としてV.Cとる関係がありV. B とV.C とは協同作用を示すと言われている.

V. B $B_{1}$ を投与した時の体内に据けるV C の消 長飞関与る報告は比輍的少く，こと飞皮属内 の総V.C量の消長飞ついては, わたくしは家 聞にしていまだその文献倿していないので， これイついて笑験を試み発表する次第である。

\section{第2章実䟻方法}

実駼使用した家鬼数よび採血，採皮の条 件は前編と全く同じであり，総V.C定量法に も変更はない。

V. B1 の投与量であるが，人体飞扔ける需 要量てついては1936年頃から世界各国で镜意 研究され, 現在では大体結論が出ている.す なわち Williams PStepp 纴 (脚気防止必要 $B_{1}$ 量 $r /$ 日 $=0.3 \times$ 非脂肪カロリー数）なる 式を立て, Cowgill は(B1要求量 $r /$ 日 $=$ $0.00426 \times$ 体重 $\mathrm{kg} \times$ 提取カロリー) という式 を出しているか，ととかく Williams, Stepp は成人 1 日1mgを最小量とし, 最適篮要量は
1 2mg と言つている.V. B 1 研究特別委員会 でも宮氏は兵士飞ついて2400カロリーにつ き需要量は扔よそ $1.7 \mathrm{ng}$. と発表し, 下田, 茶珍氏等は $1.1 \mathrm{ing}$ を必需量とし，2400 カ口 リー飞换算して1日需要量は $1.2 \mathrm{mg}$ と言つた が，その後男子では $1.5 \mathrm{mg} て ゙$ 充分であつて， $1 \mathrm{mg}$ ではや」不足, 女子では 1mg で足りる が $0.7 \mathrm{mg} て 山$ て明らか飞不足であると述へて いる. 川崎氏は $1 \mathrm{mg}$ とし柴田氏は最適需要 量は 40r pro kilo で体重 $50 \mathrm{~kg}$ 亿換算すると $1.5 \sim 2 \mathrm{mg}$ と言了. 以上より成人の V. $\mathrm{B}_{1}$ 需 要量は 1 2mg で，普通の環境では1〜1.5mg で足りるが，侍に 2mg を必要とすることも あるといらことになる。

そこで今家鬼飞 0.02mg pro kiloを投与すれ ぼ体重 $50 \mathrm{~kg}$ の成人反換算すれば，1mg とな つて，大体1日の需要量となる。 すなわちこ の最の 1 回注射ではさほど大量でもないまた 少星であないと考穴られる。このような教 から，家鬼を 0.02m pro kilo 投与群，その 10倍量の過剩投与すなわち $0.2 \mathrm{mg}$ pro kilo 投与群, さらにとの 10 倍 $2.0 \mathrm{mg}$ pro kilo 投 与群の 3 群とわけて来験を行つた。 投与方法 は皮下注射で, 使用 V. B 郕としてはメ夕ボ リン注射液（武田）を使用した。

\section{第3章実驗成綪}

第1節 ビタミン $\mathrm{B}_{1} 0.02 \mathrm{mg}$ pro kilo 注射 の場合

第 1 表拈よび第 1 図炕示すごとく，血液内， 皮属内共飞その含有する総V.CC量は, 個々の 例飞ついてみてる，100番の皮周内に淤りる 
第 1 表 Vitamin $B_{1} 0.02 \mathrm{mg}$ pro kilo を注射した場合

\begin{tabular}{|c|c|c|c|c|c|c|c|c|c|c|}
\hline \multirow{2}{*}{ 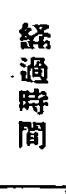 } & \multirow[b]{2}{*}{$\begin{array}{l}\text { 家 } \\
\text { 鬼 } \\
\text { 番 } \\
\text { 量 }\end{array}$} & \multirow{2}{*}{$\begin{array}{c}\text { 体 } \\
\text { 重 } \\
(\mathrm{kg})\end{array}$} & \multicolumn{2}{|l|}{ 血 } & \multicolumn{2}{|r|}{ 內 } & \multicolumn{2}{|l|}{ 皮 } & \multicolumn{2}{|r|}{ 内 } \\
\hline & & & $\begin{array}{c}\text { 注射前の } \\
\text { 耤V.C量 } \\
\text { (mg })\end{array}$ & $\begin{array}{c}\text { 注射後の } \\
\text { 總V.C量 } \\
\text { (mg\%) }\end{array}$ & 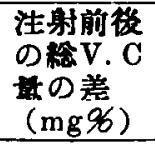 & 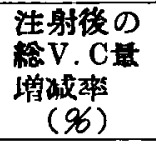 & $\begin{array}{c}\text { 注射前の } \\
\text { 総V.C量 } \\
\text { (mg\%) }\end{array}$ & $\begin{array}{c}\text { 注射後の } \\
\text { 筑V.C咅 } \\
\text { (mg\%) }\end{array}$ & 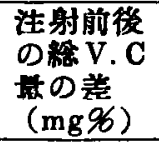 & 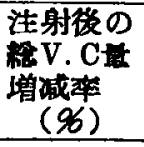 \\
\hline 一 & 96 & 1.8 & 2.54 & 2.61 & 0.07 & 2.8 & 5.12 & 5.30 & 0.18 & 3.5 \\
\hline \multirow{2}{*}{ 時 } & 97 & 2.5 & 2.82 & 2.89 & 0.07 & 2.4 & 4.20 & 4.25 & 0.05 & 1.0 \\
\hline & 98 & 2.0 & 3.34 & 3.45 & 0.11 & 3.3 & 6.21 & 6.52 & 0.31 & 5.0 \\
\hline 間 & 平 & 均 & 2.90 & 2.98 & 0.08 & 2.8 & 5.18 & 5.36 & 0.18 & 3.5 \\
\hline \multirow{3}{*}{ 二 } & 99 & 1.9 & 2.75 & 2.71 & -0.04 & -1.5 & 4.51 & 4.32 & -0.19 & -4.2 \\
\hline & 100 & 2.0 & 3.03 & 2.96 & -0.07 & -2.3 & 9.07 & 7.92 & -1.15 & -12.6 \\
\hline & 101 & 1.7 & 1.95 & 1.84 & -0.11 & -5.6 & 5.79 & 5.85 & 0.06 & 1.0 \\
\hline 䦭 & \multicolumn{2}{|c|}{ 本 均 } & 2.58 & 2.50 & -0.08 & -3.1 & 6.46 & 6.03 & -0.43 & -6.7 \\
\hline$\equiv$ & 102 & 2.4 & 3.58 & 3.51 & -0.07 & -1.9 & 5.48 & 5.84 & 0.36 & 6.6 \\
\hline \multirow{2}{*}{ 時 } & 103 & 2.5 & 2.82 & 2.85 & 0.03 & 1.0 & 4.20 & 4.20 & 0 & 0 \\
\hline & 104 & 1.9 & 3.51 & 3.67 & 0.16 & 4.6 & 8.53 & 8.40 & -0.13 & -1.5 \\
\hline 間 & 平 & 均 & 3.30 & 3.34 & 0.04 & 1.2 & 6.07 & 6.15 & 0.08 & 1.3 \\
\hline 五 & 105 & 2.0 & 4.04 & 3.90 & -0.14 & -3.5 & 6.70 & 6.82 & 0.12 & 1.8 \\
\hline \multirow{2}{*}{ 時 } & 106 & 1.8 & 2.96 & 3.06 & 0.10 & 3.4 & 5.60 & 5.79 & 0.19 & 3.4 \\
\hline & 107 & 2.1 & 3.10 & 2.99 & -0.11 & -3.5 & 6.39 & 6.64 & 0.25 & 3.9 \\
\hline 間 & 平 & 均 & 3.37 & 3.32 & -0.05 & -1.5 & 6.23 & 6.42 & 0.19 & 3.0 \\
\hline 十 & 108 & 2.0 & 2.78 & 2.61 & -0.17 & -6.1 & 4.20 & 4.14 & -0.06 & -1.4 \\
\hline \multirow{2}{*}{ 時 } & 109 & 2.4 & 3.58 & 3.58 & 0 & 0 & 6.09 & 6.39 & 0.30 & 4.9 \\
\hline & 110 & 1.8 & 2.54 & 2.61 & 0.07 & 2.8 & 5.12 & 5.18 & 0.06 & 1.1 \\
\hline 間 & 平 & 均 & 2.97 & 2.93 & -0.04 & -1.3 & 5.14 & 5.24 & 0.10 & 1.9 \\
\hline$\frac{1}{ \pm}$ & 111 & 1.7 & 2.44 & 2.33 & -0.11 & -4.6 & 3.96 & 4.08 & 0.12 & 3.0 \\
\hline 四 & 112 & 1.9 & 2.54 & 2.58 & 0.04 & 1.6 & 4.87 & 4.93 & 0.06 & 1.2 \\
\hline 時 & 113 & 2.1 & 3.13 & 3.27 & 0.14 & 4.5 & 5.54 & 5.66 & 0.12 & 2.2 \\
\hline 閑 & 平 & 均 & 2.70 & 2.73 & 0.03 & 1.1 & 4.79 & 4.89 & 0.10 & 2.1 \\
\hline
\end{tabular}

第1図Vitamin $B_{1} 0.02 \mathrm{mg}$ Pro kilo を注射した場合の

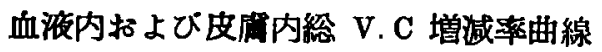

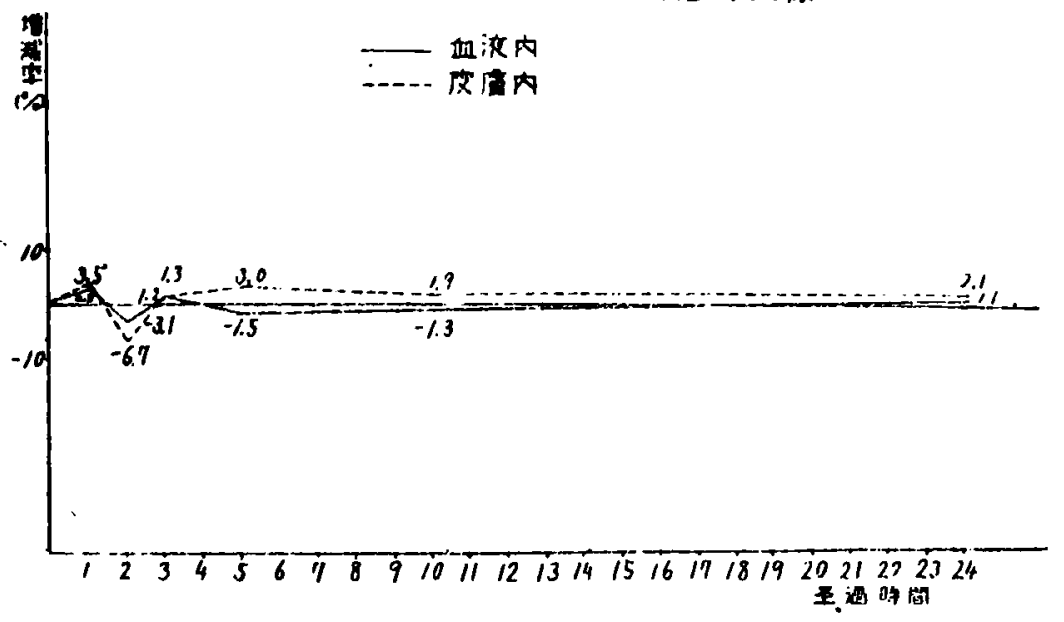

增隇率曲線を見ても，著明 の消長があるとは認めがた い.

第2蒒 ビタミン $\mathrm{B}_{1} 0.2$ mg pro kilo 注射の場合.

第 2 表および第 2 図で示 すどとく，血液内と招いて は注射後急速火総 V.C 量 が增加し， 1 時間経過後 にはすでに最高の増加率 46.096を示すに至る。そし てその後は今度は急激に增 加率が低下し，2 時間 $28.7 \% ， 3$ 時間3.5 \%となり，5時間目には一-1.0\%の減少率を 
第 表 Vitamin $\mathrm{B}_{\mathbf{1}} 0.2 \mathrm{mg}$ pro kiloを注射した埸合

\begin{tabular}{|c|c|c|c|c|c|c|c|c|c|c|}
\hline \multirow{2}{*}{ 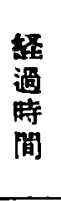 } & \multirow{2}{*}{$\begin{array}{l}\text { 家 } \\
\text { 鬼 } \\
\text { 番 } \\
\text { 量 }\end{array}$} & \multirow{2}{*}{\begin{tabular}{|c|} 
休 \\
重 \\
$(\mathrm{kg})$
\end{tabular}} & \multicolumn{2}{|c|}{ 血 } & 夜 & 内 & \multicolumn{2}{|l|}{ 皮 } & ri & 內 \\
\hline & & & $\begin{array}{c}\text { 注射前の } \\
\text { 繪V.C竞 } \\
(\mathrm{mg} \%)\end{array}$ & $\begin{array}{c}\text { 注射後の } \\
\text { 総V.C直 } \\
\text { (mg })\end{array}$ & $\begin{array}{l}\text { 洁射前後 } \\
\text { の總V.C } \\
\text { 却差 } \\
(\mathrm{mg} \mathscr{6})\end{array}$ & 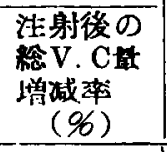 & 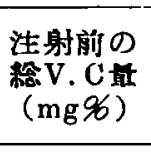 & $\begin{array}{c}\text { 注射後の } \\
\text { 総V.C䭪 } \\
\text { (mg\%) }\end{array}$ & 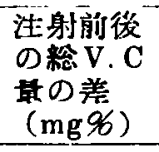 & 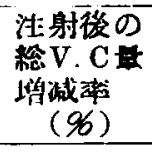 \\
\hline 一 & 78 & 2.5 & 2.02 & 2.96 & 0.94 & 46.5 & 3.47 & 3.84 & 0.37 & 10.7 \\
\hline & 79 & 1.9 & 2.61 & 3.41 & 0.80 & 30.5 & 6.09 & 6.39 & 0.30 & 1.9 \\
\hline Rf & 80 & 2.4 & 2.47 & 4.00 & 1.53. & 61.9 & 3.90 & 3.90 & 0 & 0 \\
\hline 間 & 本 & 均 & 2.37 & 3.46 & 1.09 & 46.0 & 4.49 & 4.71 & 0.22 & 4.9 \\
\hline$=$ & 81 & 2.3 & 2.44 & 2.92 & 0.48 & 19.8 & 3.78 & 3.90 & 0.12 & 3.2 \\
\hline 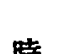 & 82 & 2.5 & 1.98 & 2.64 & 0.66 & 33.3 & 3.53 & 4.20 & 0.67 & 19.0 \\
\hline 㐿 & 83 & 2.0 & 3.13 & 4.14 & 1.02 & 32.6 & 8.83 & 9.74 & 0.91 & 10.3 \\
\hline 間 & 平 & 均 & 2.51 & 3.23 & 0.72 & 28.7 & 5.38 & 5.95 & 0.57 & 10.6 \\
\hline$\equiv$ & 84 & 2.0 & 2.02 & 2.33 & 0.31 & 15.3 & 2.44 & 2.74 & 0.30 & 12.3 \\
\hline & 85 & 2.2 & 3.13 & 3.06 & -0.07 & -2.2 & 4.20 , & 4.51 & 0.31 & 7.4 \\
\hline 時 & 86 & 1.9 & 4.17 & 4.28 & 0.11 & 2.6 & 7.31 & 7.92 & 0.61 & 8.3 \\
\hline 间 & 平 & 均 & 3.11 & 3.22 & 0.11 & 3.5 & 4.65 & 5.06 & 0.41 & 8.8 \\
\hline 五 & 87 & 2.0 & 3.48 & 3.38 & -0.10 & -2.9 & 8.04 & 9.74 & 1.70 & 21.1 \\
\hline . & 88 & 2.1 & 2.09 & 2.05 & -0.04 & -1.9 & 3.05 & 4.26 & 1.21 & 39.7 \\
\hline & 89 & 2.2 & 3.20 & 3.24 & 0.04 & 1.3 & 4.32 & 5.05 & 0.73 & 16.9 \\
\hline 間 & 平 & 均 & 2.92 & 2.89 & -0.03 & -1.0 & 5.14 & 6.35 & 1.21 & 23.5 \\
\hline+ & 90 & 2.1 & 2.99 & 3.03 & 0.04 & 1.3 & 3.90 & 3.84 & -0.06 & -1.6 \\
\hline & 91 & 2.0 & 2.58 & 2.44 & -0.14 & -5.4 & 6.15 & 6.27 & 0.12 & 2.0 \\
\hline 时 & 92 & 2.3 & 2.92 & 2.96 & 0.04 & 1.4 & 5.97 & 5.97 & 0 & 0 \\
\hline 間 & 本 & 均 & 2.83 & 2.81 & -0.02 & -0.7 & 5.34 & 5.36 & 0.02 & 0.4 \\
\hline$=$ & 93 & 2.6 & 3.13 & 3.10 & -0.03 & -0.9 & 6.39 & 6.09 & -0.30 & -4.7 \\
\hline 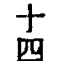 & 94 & 1.9 & 2.78 & 2.71 & -0.07 & -2.5 & 5.48 & 5.42 & -0.06 & -1.1 \\
\hline 時 & 95 & 1.8 & 2.64 & 2.68 & 0.04 & 1.5 & 7.19 & 7.31 & 0.12 & 1.7 \\
\hline 间 & 平 & 均 & 2.85 & 2.83 & -0.02 & -0.7 & 6.35 & 6.27 & -0.08 & -1.3 \\
\hline
\end{tabular}

第2因Vitamin $B_{1}$ 0.2mg Pro kiloを注射した場合の 血液内括よび皮简内総 V.C 增娍率曲線

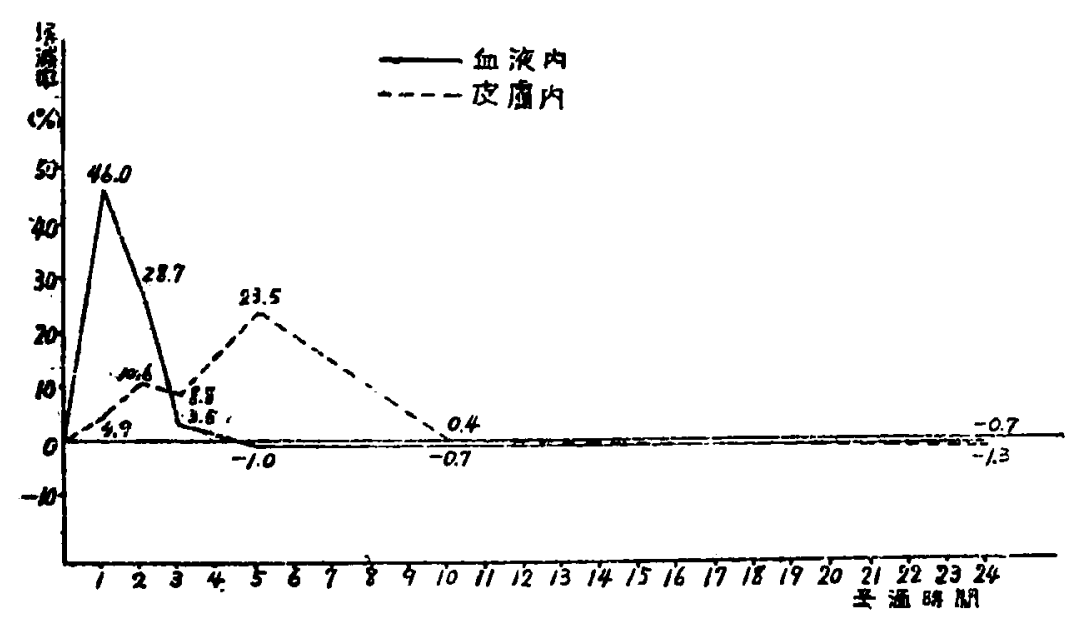

示して注射前の值に戻つて いる.これに対し皮度内に 括いては， 1 時間值 $4.9 \%$, 2 時間10.696 と徐々飞含有 量を增して行き， 3 時間で は 8.8\%と一時增加率が低 下するが，その後再び上昇 して 5 時間では23.5\%と最 高の增加率を示すに至る。 それからは含有量は減少し て10時間後には $0.4 \%$ とな り旧値に復し, 以後24時間 まで血液内括よび皮膚内共 
飞罗化は認められないようである。

第3第ビタミン $\mathrm{B}_{1} 2.0 \mathrm{mg}$ pro kilo 注射の場合.

第3表 Vitamin $\mathrm{B}_{\mathbf{1}}$ 3.0mg pro kiloを注射した場合

\begin{tabular}{|c|c|c|c|c|c|c|c|c|c|c|}
\hline \multirow[b]{2}{*}{$\begin{array}{l}\text { 経 } \\
\text { 過 } \\
\text { 特 } \\
\text { 間 }\end{array}$} & \multirow[b]{2}{*}{$\begin{array}{l}\text { 家 } \\
\text { 鬼 } \\
\text { 悉 } \\
\frac{5}{5}\end{array}$} & \multirow[b]{2}{*}{$\begin{array}{c}\text { 体 } \\
\text { 重 } \\
(\mathrm{kg})\end{array}$} & \multicolumn{2}{|c|}{ 血 } & \multicolumn{2}{|r|}{ 内 } & \multicolumn{2}{|c|}{ 皮 } & 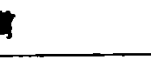 & 内 \\
\hline & & & $\begin{array}{c}\text { 洼射前の } \\
\text { 棯. C. } \\
\text { (mg\%) }\end{array}$ & $\begin{array}{c}\text { 洼射後の } \\
\text { 稳V.C竞 } \\
(\mathrm{mg} g)\end{array}$ & $\begin{array}{l}\text { 注射前後 } \\
\text { の紷V.C } \\
\text { 美 } \\
(\mathrm{mg} \%)\end{array}$ & 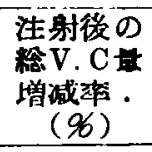 & 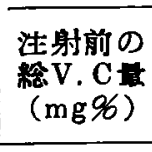 & $\begin{array}{c}\text { 注射後の } \\
\text { 狳V. C童 } \\
(\mathrm{mg} \mathscr{6})\end{array}$ & 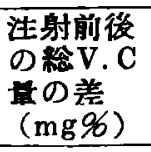 & 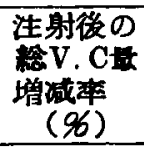 \\
\hline - & 132 & 2.1 & 3.45 & 4.21 & 0.76 & 22.0 & 3.90 & 4.57 & 0.67 & 17.2 \\
\hline 4 & 133 & 2.0 & 2.05 & 2.71 & 0.66 & 32.2 & 8.34 & 8.95 & 0.61 & 7.3 \\
\hline F & 134 & 1.9 & 2.33 & 3.17 & 0.84 & 36.0 & 5.72 & 6.09 & 0.37 & 6.5 \\
\hline 間 & 平 & 均 & 2.61 & 3.36 & 0.75 & 28.7 & 5.99 & 6.54 & 0.55 & 9.2 \\
\hline 二 & 135 & 2.0 & 3.45 & 4.04 & 0.59 & 17.1 & 3.35 & 3.78 & 0.43 & 12.8 \\
\hline 柆 & 136 & 2.0 & 1.64 & 2.37 & 0.73 & 44.5 & 4.69 & 5.18 & 0.49 & 10.4 \\
\hline 时 & 137 & 1.8 & 2.16 & 2.68 & 0.52 & 24.1 & 4.57 & 5.12 & 0.55 & 12.0 \\
\hline 閑 & 平 & 均 & 2.42 & 3.03 & 0.61 & 25.2 & 4.20 & 4.69 & 0.49 & 11.7 \\
\hline$\equiv$ & 138 & 1.8 & 2.82 & 2.82 & 0 & 0 & 3.96 & 3.78 & -0.18 & -4.5 \\
\hline 更 & 139 & 1.8 & 3.13 & 2.78 & -0.35 & -10.2 & 3.17 & 3.90 & 0.73 & 23.0 \\
\hline no & 140 & 2.1 & 3.90 & 3.97 & 0.07 & 1.8 & 6.33 & 6.88 & 0.55 & 8.7 \\
\hline 間 & 平 & 均 & 3.28 & 3.91 & -0.09 & -2.7 & 4.49 & 4.85 & 0.36 & 8.0 \\
\hline 五 & 141 & 1.9 & 2.89 & 2.54 & -0.35 & -12.1 & 5.24 & 6.88 & 1.64 & 31.3 \\
\hline$n$ & 142 & 2.3 & 1.95 & 1.88 & -0.07 & -3.6 & 4.32 & 5.48 & 1.16 & 26.9 \\
\hline & 143 & 2.2 & 2.33 & 2.33 & 0 & 0 & 5.91 & 7.43 & 1.52 & 25.7 \\
\hline 間 & 平 & 均 & 2.39 & 2.25 & -0.14 & -5.9 & 5.16 & 6.60 & 1.44 & 27.9 \\
\hline+ & 144 & 2.1 & 2.26 & 2.30 & 0.04 & 1.8 & 7.55 & 7.73 & 0.18 & 2.4 \\
\hline 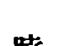 & 145 & 1.8 & 2.64 & 2.54 & -0.10 & -3.8 & 6.58 & 6.88 & 0.30 & 4.6 \\
\hline 樶 & 146 & 1.9 & 3.27 & 3.03 & -0.24 & -7.3 & 6.15 & 6.46 & 0.31 & 5.0 \\
\hline 間 & 平 & 均 & 2.72 & 2.62 & -0.10 & -3.7 & 6.76 & 7.02 & 0.26 & 3.8 \\
\hline$=$ & 147 & 2.0 & 1.84 & 1.71 & -0.13 & -7.1 & 4.02 & 4.08 & 0.06 & 1.5 \\
\hline+ & 148 & 2.4 & 3.72 & 3.83 & 0.11 & 3.0 & 6.27 & 6.46 & 0.19 & 3.0 \\
\hline 時 & 149 & 2.1 & 3.10 & 3.31 & 0.21 & 6.8 & 5.42 & 5.42 & 0 & 0 \\
\hline 間 & 平 & 均 & 2.89 & 2.95 & 0.06 & 2.1 & 5.24 & 5.32 & 0.08 & 1.5 \\
\hline
\end{tabular}

第3四Vitamin B, 2.0mg Pro kilo を注射した場合

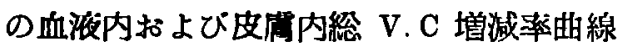

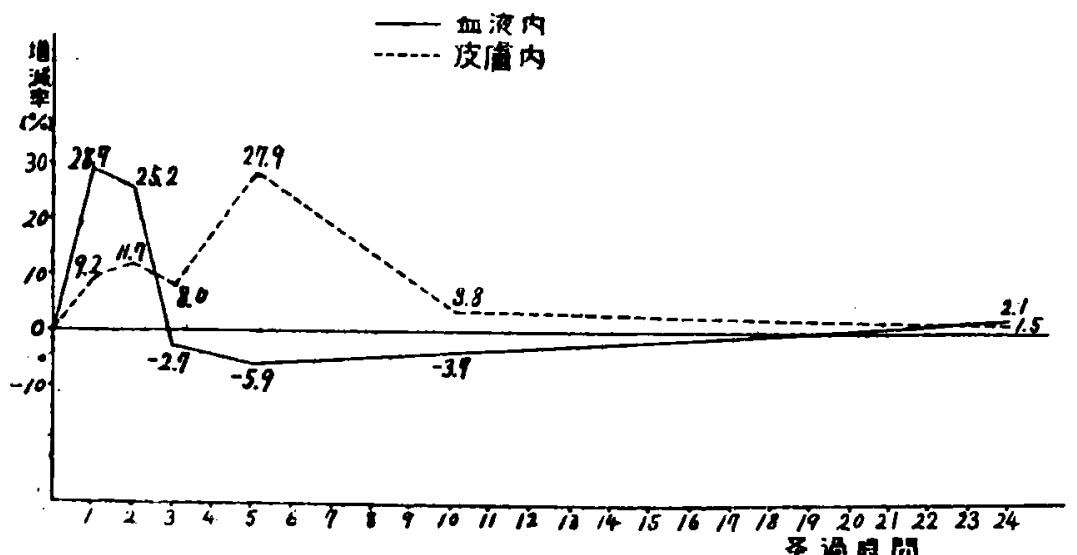

この場合の変化は第 2 節 の場合飞よく似ていて，第 3 表怙よび第 3 図でみるよ 5 K，血液内の総V.C量は 注射後 1 時間で28.7\% と最 高の増加率を示す。たよし その増加摔は第 2 節の 46.0 \%よりや小低い，つぎK2 時間で增加率がや」低下 して25.2名を示すが， 3 時間目飞なると急転直下 -2.7 96隇少率を示し大 
体旧值に復し以下 5 時間，10時間と僅かの減 少率を籶けるがまず注射前の值で経過する。

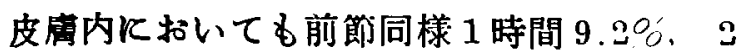
時間 $11.7 \%$ と徐々飞增加し，3時間ではや はり 8.0 名と一時低下して，5 時間で最高の 增加率 27.9 名を示す。そして 10 時間目には $3.8 \%$ となつておよそ旧值に復している。

すなわち第.2 䬦招よび第 3 節いずれの場合 Kる，V.B1 を注射してからまず血液内の総 V.Cが急激に增加し，すでに 1 時間後に最高 となり，それがまた直ちに減少して 3 時閒後 には旧值に復する形をとり，皮咸内において は，始めは徐々に增加し，2時間で小さな山 を形成して 3 時間でちよつと增加率が低下寸 るが，血液内のV.C含有量が注射前の值飞戾 るのに前後してぐつと增加し， 5 時間で最高 飞達し，大体10時間以内に再び旧值に帰ると いう形をとつている.

\section{第4章 総括ならびに考揬}

まづ拱取された V. $\mathrm{B}_{1}$ の生体内における分 布についてミ〜3の文献を参照してみるに， Leong" "食物中のV. B 1 は腸壁から吸收され て体内諸器官に移行し, ある限度までは体内 飞貯蔵されるすので, 動物体内の全 V. $\mathrm{B}_{1}$ の 50\%は筋肉中に，30\%は朋臟内にあると言了。 そして Leong Ritsert ${ }^{2)}$ む過剩の V. B 経口的に投与すると屎中に V. $\mathrm{B}_{1}$ の多量が排 泄されることを観察しているが，これについ て藤田氏は，この実験は V. B1 の結晶液を投 与したのであるから吸收されなかつたという ことは考兄られないし，また負荷後も 2 ～ 日負荷の影響が現われることから考えて，こ の V. B 1 は一旦血液中に吸收され直ちに内缄 中に貯えられて，その後徐々飞処分され直腸 から排泄されるのであろろと言つている。忚 村氏3" は白鼠をV. B 1 欠之食で飼養すると， 肝蔵，心被打よび筋肉内の V. $\mathrm{B}_{1}$ は $2 \sim 3$ 日 で急速に減少するか，大脳では 1 週間後す減 少しない，そして15日後にほ上゙安定するが， この時大量の V. B 1 (50〜100r) を皮下注射 すると,すでに 1 時間後には肝脿のみに V. $B_{1}$
が著明に增吅するが他の蔵器には增さず， 24

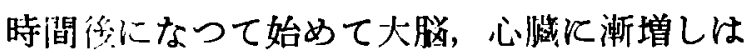
じめる。しかしこの時に朋蔵ではすでに著し く減少しているのが見られると言う鈴木氏

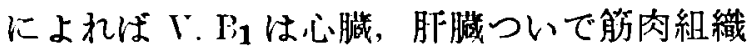
内に荒積貯㳚されると言うが，とにかく過剩 の V. $\mathrm{B}_{\mathbf{1}}$ が吸收されると1時扞脕内反入り, 徐々に大腸内飞排泄されるということである。 ところが最近の研究で藤田, 浅利氏(はV. B1 を経口的执よび避腸的に投与した場合の排泄 状況を人体で害験しているが，それによれば， 経口的負荷の場合飞は尿中に最も多く出るの は負荷後1〜4時間の間であるが尿中総排泄量 は比僌的少い，これ《反し皮下注射では $1 \mathrm{ng}$ の負荷で約 $86 \%$ が 1 日間の尿中飞排泄され， その翌日の尿には負荷の影響は認められない。

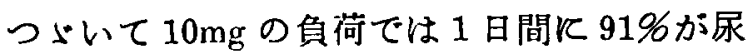
中に排淮される。 また $5 \mathrm{mg} の$ 皮下注射で負荷 後 1 時間以内飞総排沘量の66\%を排泄し，觔 肉内注射では 1 時間以内に 1 日総排泄量の 68 \%を排泄し，1 日総排泄量は負荷量の44〜53 \%であつたと述へている。なおこの他にる多 くの研究があるが大体同じよ5な結果であつ て，要するに V. $\mathbf{B}_{1}$ を非経口的に投与した場 合には直ちに肝㵶との他の淢器に分布し，過 剩はすで飞 1 时間位でその大半を尿中に排渄 されるものと思われる. 本編と括いてV. B 皮下注射後, 血液内総V.C星がすでに1時間 後に括いて著明な增加を来たし， 3 時間では

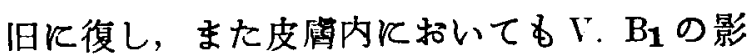
響と思われるV.C量の增加が10時間以内に旧 飞復するということは，上記のごとく，過剩 の $\mathrm{r} . \mathrm{B}_{1}$ が数洔間以内に大部分体外飞排泄さ れるものとすれば，当然のこと〉考兄られる。 つぎに V. B $B_{1}$ の生理作用についてもいくた の研究が発表されているが，今日では広沉に 一般細胞の新陳代謝に必要なるのということ そなつている，その先靴は Funk ${ }^{\text {) }}$ であつて

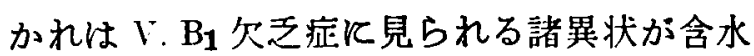
丠素代謝障碍によるものであろろと推論した のである，その後多くの研究者により，糖質

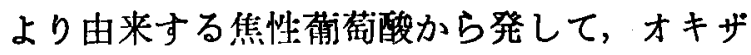


ル䤉酸, 1ソクエン酸, $\boldsymbol{\alpha}$ 一ケトクルタール酸, フマール酸, リンゴ酸等いわゆるKrebsの(4 ヂカルポン酸系が組織の物質代愔にきわめて 重要な役制を演じていることが碓定された。 そしてけ. B 1 は Lohmann u. Schuster ${ }^{(6)}$ が確定

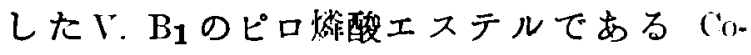

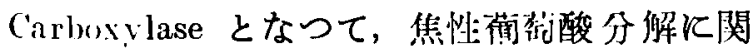
与していることは周知の事奏である。すちろ ん唯単に $r . B_{1}$ 単独の作用ではなく, 他の種 々の因子をこれに加わつていることは確かで はあるが，さらにまた上記 Krebs のサイク ルにもV. B 1 が或程度関与していることも山 田氏7の言らごとく容易に考えられることで ある，ところで第 1 編にも述へたように萩野 氏は，マンノーゼ拈よびクルコーゼからヂ トクロン酸を経てけ、Cが合成されることを確 認したが，さらにも少し氏9の言うところを 述べる， 2.3 ヂトクロン酸より前の中間 物質としてマンノーゼ，クルコーゼの酸化 物であるd一マノン酸括よびd一グルコン酸 があると言い，つがいて萩野，三島氏 ${ }^{9)} は$ マンノーゼからマノン酸に変化させるすのは Diphosphopyridinnucleotid を補酵素とする Dehydrase なる醉素であつて，クルタチオ ンは本醉素の水素受体となると報告をしてい る. 三臭氏 ${ }^{10)}$ は上記 Krebsのサークルが水晶 体の物質代謝過程にも関与していることを証 明し，同時に $\alpha$ ケト酸である2一ケトケロン 酸共存していて，これからもV.Cが明らか そ合成されるのを見ている，さらにまた樋口 氏11)牛, 馬, 豚の水晶体で 2一ケト，1一グロ ン酸よりV.Cの形成を証明し、つょ゙いてかれ²1 は5一ケトーdークルコン酸からすV.Cが形 成されることを報告した そして萩野氏はこ のV.C. 形成過程は肝淢に括けるV.C形成過 程にも適用されるが，たよ゙このV.C 形成は 筋肉その他の組織で行われているいわゆる解 糖形式とは一致しないるのであつて，解楁醂 菜もこれには関与せずまた解糖に必要な附燐 作用る不必要であると述べている，とにかく 上記のごとき糖代謝を介してのV， $\mathrm{B}_{1}$ とV.C との関係について詳細に報告されたものは見
当らず，関係ありときつぱり断定は出来ない が，また全く関係がないとも言い切れないよ 万飞思われる。

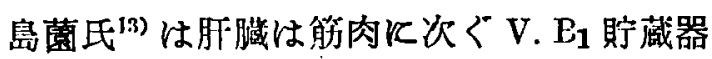
官で体内全舅の 4 分の 1 を保有すると言い，

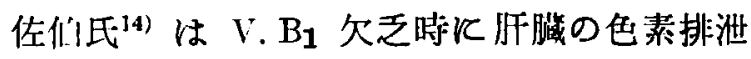
機能の低下を認め, 大橋, 重見および木村 氏 ${ }^{15)}$ はV. B 1 欠乏食䬦で家鬼肝践の果煻処 理機能の低下を認めた。井上氏 ${ }^{16)}$ も人体 V. B1 欠乏は肝㖪の機能低下 (果糖処理能, サントニン酸ソーダ負荷試験, 尿中ウロビリ ノーダン反応）を来し，とくに果糖処理能の 低下が著しいと述べている。 また美間氏 ${ }^{17)}$ 括 よび Sure u. Abderhalden ${ }^{18)}$ 等は V. B 肝糖原質を增加させると言い，Uhlmann ${ }^{191}$ 扣よび掯水氏 ${ }^{20)}$ は胆汁分泌機能!克進させ ると報告している。 また Funk, Douglas ${ }^{21)}$ 扣よび林氏 ${ }^{22)}$ は V. $B_{1}$ 欠之時には甲状腺の 萎縮が現われ，チロキンンの分泌障碍が起る と述へ，田坂氏 ${ }^{23)}$ は V. B 1 は甲状腺機能元 進状態に対して好影響を及洼すと言つている。

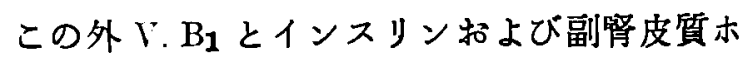
ルモン等との関係についての報告す 2 \% つて，大体協同作用的に衝くようであるが断 定的でなく，とにかくなんらかの相関々係は あることは考えられる。

一般K V.A と V.C とは拮抗的作用寸 るが V. $B_{1}$ とV.C とは協同作用を示すと言 われ，西沢氏 ${ }^{24)}$ は鳩の白米病に対するV. $\mathrm{B}_{1}$ の治效はV.C 飞よつて補強されると言い, 大島, 高橋, 村上氏2n等は海猽の壊血病飞 対するV.Cの予防扣よび治湶作用は、V. $\mathrm{B}_{1}$ の 添加によつて堌強すると述へている，井上氏

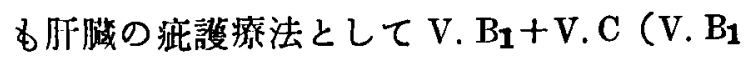
$5 \mathrm{mg}$ K対し V.C 150〜300mg の割合) が対 照に此へて優れていることは明白であると報 告している そしてその説明として V.C 欠 之時の肞臟糖原質は減少し， V.C，の投与飞 よつて增暑するからであると言つている，村 上氏 ${ }^{26)}$ む V.C 欠乏状態飞ある海猽肝臓のイ ンドール解毒機能障害はV. $\mathrm{B}_{\mathbf{1}}+\mathrm{V} . \mathrm{C}$ Kよ り著しく軽減されると言う。向田氏 ${ }^{27)}$ は肝 
腈のフェノール抱合解毒機転に対し， V. $\mathrm{B}_{\mathbf{1}}$ 括よび V.C は充進的作用し，エーテル硫 酸合成機転に対しては，V，B1 は中等量 (2mg) は促進的に大量 $(5 \mathrm{mg})$ は抑制的飞作 用するが，V.C はわずかに促進的に作用す るK止まり，クルクロン酸抱合機枟に対して は両者共著しく促進的飞作用するのを認め， これらの作用は主として肝睵の糖原質がビタ ・ミンにより增加した結果によるすのであろう と報告をしている.

以上諸家の報告から教えて，今 $V: \mathrm{F}_{\mathbf{1}}$ を 動物飞投与した場合、V. $\mathrm{B}_{1}$ は生体の含水荻 素代謝に欠くべからざるビタミンであるから， その大量投与は生体内の含水岸素代謝を確か 飞促進させるはずである，その結果家鬼のご とき自己体内で V.C を合成し得る動物では， 2ー3ーケトクロン酸や 2一ケトグロン酸ある いは 5一ケトーdーグルコン酸から V.Cが合 成されるょうに，Krebsのサークルの中のも のか, または V. B . の関係した糖原質の誘 導体から V.C が生成されないとは断言でき ないはずである.さらにV.B $B_{1}$ と.C どが 肝機能, 甲状腺機能または副觜皮澌ホルモン 等を仲介として，なんらかの相関々係を持つ ていることは充分将えられることであつて，

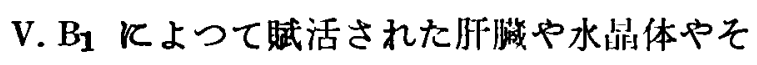
の他の歲器の機能元進のために V.Cの合成 が促准されるということす無視できないとこ ろである。そのいずれが主であるか従である か，あるいはまたいずれか一方だけが関与し ているのかまだよく解らないけれど，今迄述 ベたとてろを参考として以下本編の実験結果 を考按してみる.

オカラの V. B 1 含有量は滕田氏 ${ }^{29}$ とよれ

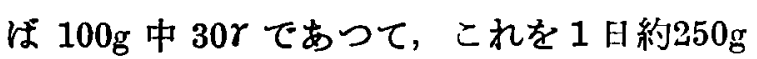
与えているのであるから実駰家鬼はV. B 1 を 1 日 $0.09 \mathrm{mg}$ 程度を摄取しているわけで,

V. B 飞不足してはいない。

それ故に V. B は，なるほど余分にこれだけ挆与されたこと Кはなるのであるが，過剩投与と言う程でも ない。そのために䛶験結果にもほとんど著明
の翌化を認めなかつたのであろう。

$0.2 \mathrm{mg}$ pro kilo の注射では，丁度前者の 10倍量にあたり相当の過剩投与になつている.

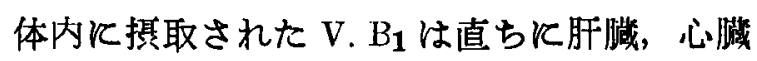
その他の歲器飞分布されるが，V，C 合成睵 器へ運搬された V. $B_{1}$ は上述のごとき関係 で V.C 合成能を一時的にしかも急速に促進 するものと思われる。そして2一ケトクロン 酸などから V.C が形成されるのは大体 1 洔 間以内とされているので，この時合成された V.C は注射後 1 時間位ですでに大量血液中 に放出されるるのと考えられる。しかし他の 蔵器組織には格別 V.C 不足があつた訳では ないので，すぐには組織中に V.C が移行せ ず，徐々に移行して行くために皮内咸に和け る総 V.C 量は溸次增加の形をとつて行く. ところが投与された V. B はこれまた 1 時 間前後でその大量が体外飞排泄されるために， 過剩 V. B 1 の影響も短時間で終り， V.C 形 成もすぐに平常状態に戻るであるろ。そして 一時的に血腹中に增加した V.C は一部は尿 中飞排泄されるが一部は組織内に運ばれてそ こで消費，分解され，V. $\mathrm{B}_{1}$ 投与後大体 10 時間で家鬼体内に括けるV.C は平衡状態に 危るものと思われる。この復昍㴗する時閒 であるが，皮咸内の V.C 含们量が注射後 5 時間前後で最高に達しているので，その過剩 のV.C：が分解され旧に復するのにも括よそ 5 時間前後か」るものと考えてるよかろうか， この血液内拈よび皮周内の変化はあくまで全 身的な変動の現われの一部であつてかくのご とき䉍単な関係で割り切れるものであなく， また本実験でも 5 時間と10時間との中間の值 を測定していないので，もつと早いかも知れ ないしなんとも言えない。

つぎk $2.0 \mathrm{mg}$ pro kiloを投与した場合の 血液内抢よび皮膚内総 V.C 量の消長は，前 の $0.2 \mathrm{mg}$ 投与の場合と余く同じ傾问を示し ているので，V. $\mathrm{B}_{\mathbf{1}}$ 注射のために薏起され た家鬼体内 V.C の変動にもまたあまり差異 はないものと洘えられる。たよ゙この場合投与 量が前の10倍, すなわち普通 1 日篅要星の 
100倍という大量であるにあか」わらず，血 液内の最简增加率は前の場合よりか元つて 少いという結果が出ている。しかしこれは $0.2 \mathrm{mg}$ 投与の場合の 1 時間值の中の 1 例が特 飞高い值を示した為であつて，第 2 抢よび第 3 表を比较してみて屾者にあまり差のないこ とがわかる，皮楷内総 V.C の增減率曲線は $0.2 \mathrm{mg}$ 投与の場合とほとんど差異が見られな い、しいて言えば後の方がわずかに最高值が 大であるようだが，これるこれ位の茎では有 意のすのと思われない。

要するに V. B 1 を過剩投与した晹合の血液

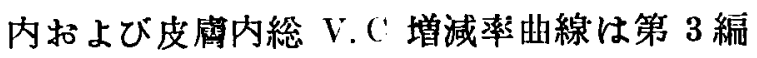
の V.A 過剩投与の場合のそれとよく似てい るが，か」る変化を現わす機転は全く異なり， 本編の場合はV.B1 により生体内の物質代 謝が旺盛となつて V.C. 合成を促進し一時的 K体内 V.C 合成を促進し一時的飞体内 V.C 合成，消費の不均衡を惹起するるのと想像さ れる.

そして家鬼飞対しては 0.2mg pro kilo と いう投与是は十分過剩量であつて，これ以上 いくら大量に投与しても，それは全く体内の 物質代謝に関与することなくすみやかに排泄 されてしまうるのと考学るのが穻当ではない だろうか。すなわち V. B1 の致死量は極め て大星であつて，動物の㮔類によつてる買る が，血管内注射でも $125 \sim 350 \mathrm{mg}$ pro kilo, 皮下注射ではその 6 倍と言われているから， 2.0mg pro kilo 位の投与量では，過剩となつ たV.B $\mathrm{B}_{1}$ は生体になんら障碍を与えること なしに排浛されるるのと思われる。

な括本編の実験結果から考元て，家鬼と人 体とは勿椧条件は異るが，普通の場合はげし いV. $\mathrm{B}_{1}$ 欠乏症でないかぎり，人体に 1 回 $10 \mathrm{mg}$ 以上の注射を行つてもあまり意味がな いし，また V. B $\mathrm{B}_{1}$ 欠乏症です $10 \mathrm{mg}$ 程度の V. $B_{1}$ 剂を 5 時間毎位飞注射すれば生体の組 織に継続的な刺戟を与えることができるかる 知れない。

最後飞, 皮或内総 V.C. 增減率曲線が第 さ 扣よび第 3 図でみるよう飞，3時間で一時增
加率の上昇が停止しているようであるが，こ れが偶然の一致かまたはそんな性質を持つて いるものかはよくわからない.

\section{第5章 結論}

策鬼にビタミン $\mathrm{B}_{\mathbf{1}}$ を投与（皮下注射）し， その後の血液内括よび皮展内総 V.C 量を劓 時的に定量して次の結果を得た。

1) ビタミン $\mathrm{B}_{1} 0.02 \mathrm{mg}$ pro kilo 投与では・ ほとんど有意の翋化を示さない。

2) ピタミン $\mathrm{B}_{1} 0.2 \mathrm{mg}$ pro kilo 投与では 血液内総 V.C 量は, 注射 1 洔間後飞最高の 增加率を示し $46.0 \%, 2$ 時間 $28.7 \%, 3$ 時 間3.5\%と 2 時間目から急速に增加率が低下 し 3 時間でほとんど旧值に復する。皮膚内に 扣いては，注射後 1 時間で $4.9 \%$ の增加率を 示し，それ以後は血液内の V.C 增加歓が低 下するのと逆比例的飞俆々飞增加率が上昇し, 2 時間 10.6\%，3 時間8.8\%，そして 5 時間 で23.5\%と最高率を示すが，その後は再び俆 々に增加率が低下して，10時間で注射前の值 そ復する。

3）ビタミン E1 $2.0 \mathrm{mg}$ pro kilo 投与で は, 血液内総 V.C 量は注射 1 時間後飞 28.7 \%，2時間 $25.2 \%$ とれまた 1 時間で 最高增加率を示し，前と同しく 3 時間で

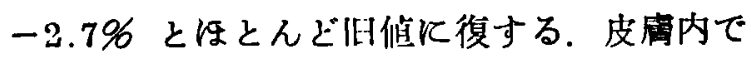
は $0.2 \mathrm{mg}$ pro kilo 投与の場合と全く同しょ 了な增減率曲線を画き，1時間 9.2\%，2時 間 $11.79 \% ， 3$ 時間 $8.0 \%$ ，と徐々飞增加率 が上昇し， 5 時間で $27.9 \%$ と最高の增加率 を示し，10時間では $3.8 \%$ と大体注射前に近 い值を示す。

4）これらの結果を，V. B 1 が:含水炭素 代謝，肝淢機能扣よび甲状腺機能等を介して V.C 合成と関係を有しているのではないか という点から考察を試みた。

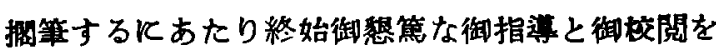
賜つた恩帽根岸教授に蒜心から感謝の䁍を搭げま す. 


\section{主 要 文 献}
1) Leong - Biochem. J., 31, 367, (1937)
16）并上．22回B委弝事，(昭23）
2)-Ritsert : Klin. Wschr., 1397, (1938)
17）美間 - 内分泌会綕，5，1，580，(昭4）
3）中村：海軍々医，32，993，(昭18）
4) 藤田, 浅利 . ビタミン，117，(昭23）
18) Sure u. Abderhalden : Die Vitamin u. ihre klin. Anwendung, S., 30, (1936)
5) C. Funk $\cdot$ Z. physiol. Chem., 89, 378, (1914)
19) Uhlmann Z. Biol., 68. (1918)
6) Lohmann u. Schuster - Biochem. Z., 294. 188, (1937)
20）清水 24回B委記事,（昭23）
21) Funk, Douglas : J. physiol., 47, 475, (1914)
7）山田：産婦人科の世界，2，107，(略25）
22）林 · 京都医言，21，1662，(1924）
8）萩野 。眼科学誌，55，8，493，(昭26）
23）田坂 東京医誌，52，8，(昭13）
9）萩野.三島·眼科学誌，56，7，576，(昭27）
24）西沢大阪医䓌，35，493，717，(昭11)；36，
10）三岛 眼科学誌，55，11，1004，(昭26） 621，(昭12)
11）桶口 . 眼科学誌, 56, 6, 345，(昭27）
12）㛚口 - 眼科学誌，56，11，1217，(略27）
25）大鳥. 高曆. 村上. 実験消化器病学，13，821, (吸12)
13）鳥菌：新鼬医誌，62，97，(昭23）
26)村上：同上，14，379，(昭14）
14) 佐伯：実倹消化器病学，3，11，1309，(昭4）
15）大橋. 重見. 木村：実臨消化器病学，8，5,
27)向田同上, 18，823，898，(䀤18）
28）藤田ビタミン $\mathrm{B}_{i}, 318$ ，(昭23） (昭8) 